\title{
Investigating and stimulating primary teachers' attitudes towards science: Summary of a large-scale research project
}

\author{
Juliette Walma van der Molen ${ }^{\mathrm{a}}$, Sandra van Aalderen-Smeets ${ }^{\mathrm{a} *}$ \\ ${ }^{a}$ University of Twente, the Netherlands \\ * Both authors contributed equally
}

Article received 13 May 2013 / revised 19 September 2013 / accepted 19 September 2013 / available online 20 December 2013

\begin{abstract}
Attention to the attitudes of primary teachers towards science is of fundamental importance to research on primary science education. The current article describes a large-scale research project that aimed to overcome three main shortcomings in attitude research, i.e. lack of a strong theoretical concept of attitude, methodological flaws in attitude research, and ineffective interventions. The research project included (a) the development of a new theoretical framework for teachers' attitudes towards (teaching) science, (b) a new validated survey instrument (the DAS) to measure the different underlying components of primary teachers' attitudes toward teaching science, and (c) an in-service professional development training course based on the previously developed theoretical framework. The framework of attitude consists of three dimensions: cognitive beliefs, affect, and perceived control, each consisting of several subcomponents. By means of the survey instrument we investigated the effects of the attitude focussed training course. The course aimed to improve attitude by creating awareness about teachers' own attitudes, stimulating their scientific attitudes and curiosity, and training inquiry and thinking skills. The course refrained from providing recipe-like example lessons, materials, or methods. Using a pre-post, experimental-control design we showed that the course significantly improved the affective and perceived control dimension of attitude. Teachers enjoyed teaching science more, showed increased self-efficacy, and felt less dependent on external factors. This project shows that genuine attitude improvements of primary teachers can be accomplished by attitude focussed professional development.
\end{abstract}

Keywords: Science education; Attitude towards science; Professional development; Inquiry based learning.

Corresponding author: Sandra van Aalderen-Smeets, PO Box 217, 7500 AE, Enschede, the Netherlands, Sandra.vanaalderen@utwente.nl 


\section{Introduction}

The study on attitude towards science has received considerable attention over the last decades (Osborne, Simon, \& Collins, 2003; Osborne \& Dillon, 2008). In our society, we are increasingly dependent on science and technology in all kinds of ways. Despite this, a large section of the population has little scientific or technical knowledge and attitudes towards science and technology are not very positive. Although this lack of interest often only really manifests itself when young people make their choice of subjects at secondary school, most pupils have already formed stereotypical images of and negative attitudes about science and technology before the age of 14 (Osborne \& Dillon, 2008; Tai, Qi Liu, Maltese, \& Fan, 2006; Turner \& Ireson, 2010).

International research (e.g., Jarvis \& Pell, 2004) shows that this negative image of science subjects is also found among primary school teachers. Many primary teachers feel insufficiently capable of providing education in the field of science. They find it difficult to deal with pupils' questions in this area and prefer to fall back on standard textbooks or highly structured materials or exercises. When this type of practice is the norm, it is no wonder that pupils' attitudes with regard to science and technology are difficult to change for the better.

Primary schools and their teachers therefore play a crucial role in determining the attitudes and images of students towards science and improving primary teachers' attitudes towards science is one of the major challenges in today's science education (Haney, Czerniak, \& Lumpe, 1996; Osborne, Simon \& Collins, 2003; Osborne \& Dillon, 2008). Research has shown that (pre-service) primary teachers' scientific literacy is low, that their attitudes towards science are mostly negative, and that primary teachers share a number of characteristics that impede the stimulation of science learning and of positive attitudes towards science among their pupils (Harlen \& Holroyd, 1997; Jarvis \& Pell, 2004; Tosun, 2000; Yates \& Goodrum, 1990).

Professional development should therefore pay explicit attention to improving the attitude of (preservice) primary teachers towards science (Haney, Czerniak, \& Lumpe, 1996). However, although primary teachers' attitudes toward science have been investigated widely, scientific progress in this field has been slow. In our view, there are three important and in part related reasons for this poor development. First, until recently the theoretical conceptualization of the construct of primary teachers' attitudes towards science was poorly articulated, both in research and in educational change projects (Barmby, Kind, \& Jones, 2008; Bennett et al., 2001; Coulson, 1992; Osborne et al., 2003; Pajares, 1992). Many studies provided incomplete definitions (or no definition at all) for the construct of attitude, failed to explicate the components of attitude that they measured, or did not distinguish between attitudes towards science and other related concepts (e.g., opinions or motivation).

A second reason for the slow scientific progress in research on primary teachers' attitudes towards science is the lack of reliable and valid attitude measuring instruments that accommodate to necessary theoretical and statistical standards (Gardner, 1995; Reid, 2006). A recent review of the literature points at important flaws in the methodology of a majority of studies, such as weak psychometric properties and failure to pilot-test, validate, and evaluate the instrument according to current psychometric standards (van Aalderen-Smeets \& Walma van der Molen, 2012).

A third reason for slow progress in primary teachers' attitude development may be found in the interventions that are directed at teachers' professional development. Most professional development projects that aim to improve science education in primary school focus on improving classroom didactics and provide a collection of standardized, recipe-like science lessons. Although this might improve the knowledge of teachers regarding science content or pedagogical content knowledge, it does not automatically lead to improvements in their attitudes toward science. 


\section{Recent research}

To remedy these shortcomings in research and in the professional development of primary teachers' attitudes towards science, we established a large-scale project over the past three years that included (a) the development of a new theoretical framework for teachers' attitudes towards (teaching) science, (b) a new validated survey instrument to measure the different underlying components of primary teachers' attitudes towards teaching science, and (c) an in-service professional development training course that was based on the previously developed theoretical framework. The project was based on the contention that only when teachers possess a positive attitude towards teaching science and towards inquiry-based learning, they will be motivated and able to seek and use science content in their lessons, to use inquiry-based learning in class, and to affect pupils' scientific attitudes and their attitudes towards science in a positive manner. The present article presents an overview of the results of this integrated project.

\subsection{Theoretical framework}

The development of a new attitude framework implied disentangling the construct of primary teachers' attitudes towards science. As described elaborately in the theoretical article that resulted from this project (van Aalderen-Smeets \& Walma van der Molen, 2012), we aimed to explicate and structure the range of underlying components or dimensions of primary teachers' attitudes towards science. The framework was based on an extensive review of previously used concept definitions of the construct of primary teachers' attitudes towards science and we related these components to general psychological attitude theories, such as the Tripartite Model of attitudes (e.g., Eagly \& Chaiken, 1993) and The Theory of Planned Behaviour (e.g., Ajzen \& Fishbein, 1980). This resulted in a framework of attitude consisting of the following three main dimensions: cognitive beliefs, affect, and perceived control. Cognitive beliefs refer to teachers' beliefs and opinions about (a) the relevance of science and science education, (b) beliefs about the relative difficulty of teaching science, and (c) gender stereotypical beliefs regarding science and science teaching. The second dimension of affect contains the independent subcomponents of (a) enjoying (teaching) science and (b) anxiety related to (teaching) science. The third dimension, perceived control, refers to the amount of control teachers perceive to have over (teaching) science and it consists of (a) self-efficacy (an internal sense of control, such as the perceived capacity to teach science) and (b) perceived dependency on context factors (beliefs about the extent to which a teacher is dependent on external factors to teach science, such as the availability of teaching-methods or materials, enough time, or other resources). The outcomes of our review of concepts suggested that, in addition to internal beliefs and feelings associated with self-efficacy, the beliefs and feelings that teachers have about external (i.e., contextual) factors are closely related to teachers' sense of being in control. In our view, the perception of teachers regarding their dependency on context factors (e.g., their belief that they can teach science only if their school ensures the availability of the proper materials and sufficient preparation time) is an indispensable component of a complete theoretical framework of primary teachers' attitudes toward science. The development of the theoretical framework provided a new theoretical basis for measuring primary teachers' attitudes towards science and for interventions aiming to improve their attitude, two issues that were pursued in the studies described below.

\subsection{Validated survey instrument}

Based on the theoretical exercise described above, we developed a new measurement instrument: the Dimensions of Attitudes towards Science questionnaire (DAS). After construction of the first version of the DAS, we investigated its validity and reliability by means of a qualitative in-depth focus group study and a quantitative survey study (Asma, Walma van der Molen, \& van Aalderen-Smeets, 2011; van AalderenSmeets \& Walma van der Molen, 2013a). Using the theoretical framework as a basis for the development of a new attitude instrument ensured that the complete range of relevant attitude dimensions and subcomponents was incorporated in the instrument. In addition to the subscales that correspond to the components of the theoretical framework of attitude, scales measuring teachers' views on science and their intended science teaching behaviour were included in the questionnaire. 
The pilot-tested DAS questionnaire was distributed digitally to in-service and pre-service teachers. A total of 556 respondents returned a complete questionnaire ( $80 \%$ female, mean age 31 years). The DAS instrument was evaluated at multiple levels; i.e. the validity of the overall structure of the instrument was investigated by confirmatory factor analysis, the internal consistency of the subscales was determined by Cronbach's alpha coefficient, and to assess the discriminating ability of each item, we looked at the standard deviations of each item and their response-range. Our results supported the validity, reliability, and discriminating ability of the DAS instrument. The resulting factor structure corresponded to the underlying theoretical model. The obtained seven-factor solution confirmed the hypothesis that the DAS questionnaire is measuring the seven underlying sub-components of the attitude framework. Furthermore, the results of the internal consistency analyses showed high internal consistency in all seven subscales. Also, regression analyses showed that scores on the subscales of Affect and Perceived Control were predictive of the scores on Intended Behaviour, indicating predictive validity. Finally, all items in the revised DAS instrument showed large response variation, indicating a strong ability to discriminate between respondents displaying different beliefs, feelings, and thoughts toward teaching science. These results show that the DAS instrument is a valid, reliable, and comprehensive survey tool, which is able to measure a complex and difficult motivational concept (for a complete description of the instrument, see: van Aalderen-Smeets \& Walma van der Molen, 2013a).

The DAS instrument thus proves to be a promising instrument within the field of science education and teacher training at primary school level. It can be utilized as a research instrument for effect studies of training courses and other interventions aiming to professionalize primary teachers. Furthermore, it can serve as a diagnostic tool for adapting training courses and interventions to the individual needs of pre- and inservice teachers. And finally, it can be used as a coaching tool for making primary teachers aware of their own view of science and their (changed) attitudes toward teaching science. By means of these different uses, the DAS instrument could become a highly valuable instrument for making progress within the field of science education in primary schools.

\subsection{Professional Development}

Our in-service training course was also based on the different underlying components in our theoretical framework and consisted of six 3-hour meetings spread over six months (Walma van der Molen, van Aalderen-Smeets \& Groot Koerkamp, 2011). The course focused on creating awareness about teachers' attitudes towards teaching science, awareness about their views on science, and awareness about their attitude towards inquiry-based methods of learning. These attitudes were reflected upon and challenged by means of assignments, exercises, questioning, information transfer, and research activities like experiments. In addition, each of these course elements was accompanied by activities that stimulated teachers' own curiosity, inquisitiveness, critical thinking, reflection and metacognition, and higher-order thinking. Most importantly, the training course refrained from providing recipe-like example lessons, pre-structured materials, or predefined methods. During the meetings, teachers engaged in coursework that prepared them for take-home assignments. During the final meeting, participants presented a science and inquiry-based project that they had developed and carried out with their pupils (see Appendix for a general overview of the core elements of the course).

To test the effectiveness of our course, we used a pre-post test, experimental-control group design to asses changes in teachers' attitudes toward teaching science over time (experimental group $n=49$, control group $n=45$ ). The experimental group participated in the training course, while the control group did not receive any formal training. However, the control group did consist of teachers that reported to be interested in science education. We used our 'Dimensions of Attitude toward Science' (DAS) instrument to measure quantitative changes in teachers' attitudes towards teaching science. In addition, we used qualitative, openended, self-report measures to investigate changes in scientific attitude, perceptions of science, and attitude towards inquiry-based methods of learning. 
Two out of three attitude components showed significant improvements (see Table 1), indicating that the training course had a positive effect on attitude towards teaching science (van Aalderen-Smeets \& Walma van der Molen, 2013b). Participants in the course gained a more positive attitude in the affective and perceived control dimension of attitude, compared to the control group. This means they enjoyed science teaching more, showed increased self-efficacy, and felt less dependent on recipe-like, standardized methods, top down instruction, and the availability of pre-organized projects and materials. Participating teachers in the training course did show a significant improvement on the remaining attitude components (less anxiety when teaching science, believing science teaching is more relevant, and less stereotypical beliefs), but this improvement was not significantly different from changes in the control group, even though the changes in the control itself were not significant, see Table 1 . This could be due to the relatively high interest in science and engagement with science of the control group, i.e., because they engaged in science related teaching and activities in between the pre- and post-test, they improved their attitudes slightly. On the open-ended questions, teachers indicated that, after participation in the course, they found science to be less complex and to use inquiry-based methods of teaching more often in both science-related lessons and in other school subjects. In addition, teachers' responses showed enhancement in their scientific attitude, i.e., they became more curious, more critical, and more explorative. Furthermore, teachers' perceptions and expectations of their pupils changed; teachers reported to be surprised by the excellent achievement of some pupils during science lessons (for a more detailed report about this effect study, see van Aalderen-Smeets \& Walma van der Molen, 2013b).

Table 1.

Attitude toward teaching science; comparison of attitude scores between trained and control group on pre and post-test. Mean difference scores of the trained and control group are presented in the left columns. The right columns present the results of an ANOVA analysis for each component of professional attitude (significant effects are printed in bold).

\begin{tabular}{|c|c|c|c|c|c|c|c|}
\hline & \multicolumn{2}{|c|}{ Trained group } & \multicolumn{2}{|c|}{ Control group } & \multirow[b]{2}{*}{$\mathrm{F}$ value $(1,104)$} & \multirow[b]{2}{*}{$\mathrm{p}$} & \multirow[b]{2}{*}{ Eta } \\
\hline & MDiff & SD & MDiff & SD & & & \\
\hline \multicolumn{8}{|l|}{ Cognition } \\
\hline Relevance & $.24^{\mathrm{a}}$ & .59 & .08 & .64 & 1.9 & .17 & .02 \\
\hline Gender & $-.27^{\mathrm{a}}$ & .82 & -.06 & .87 & 1.6 & .21 & .01 \\
\hline \multicolumn{8}{|l|}{ Affect } \\
\hline Enjoyment & $.53^{\mathrm{a}}$ & .80 & .14 & .90 & 5.6 & $.02^{\mathrm{b}}$ & .05 \\
\hline Anxiety & $-.39^{a}$ & .77 & -.15 & .95 & 2.1 & .16 & .02 \\
\hline \multicolumn{8}{|l|}{ Perceived Control } \\
\hline Self-efficacy & $.40^{\mathrm{a}}$ & .55 & .11 & .51 & 7.6 & $.01^{\mathrm{b}}$ & .07 \\
\hline Context dependency & $-.98^{\mathrm{a}}$ & 1.10 & .09 & .98 & $27.8(1,102)$ & $.01^{\mathrm{b}}$ & .21 \\
\hline
\end{tabular}

MDiff = Mean difference score $(\mathrm{T} 2-\mathrm{T} 1), \mathrm{SD}=$ Standard deviation,

${ }^{a}$ Significant improvement within group (paired T-test between pre-test and post-test within group)

${ }^{\mathrm{b}}$ Significant difference between improvements of trained and control group (ANOVA interaction effect)

This study indicates that focusing explicitly on primary teachers' attitudes in a training course does improve the beliefs, feelings, and perceived control primary teachers have regarding science education and inquiry based methods of learning. 


\section{Future directions}

This large-scale research project provides valid tools and new approaches for improving and assessing primary teachers' attitude towards (teaching) science and opens the door for several future directions in attitude research. The attitude effects reported here are short-term effects based on self-reports. Further research is needed to investigate the long-term effects of teachers' attitude change and changes in their actual teaching. Furthermore, more research is needed on the effects of improved teacher attitudes on their pupils' or students' attitude toward science and their career choices in their future school career. The results presented here are not only relevant for primary education. The gained knowledge about improving attitudes towards science can be applied in interventions, professional development, and research aiming to improve secondary school students' attitudes towards science as well. In addition, the approach taken in this research project, i.e., building a theoretical framework, then constructing a valid instrument, and testing the effects of a new intervention, may be followed for other lines of research, such as research on attitudes towards inquiry based learning or on attitudes towards the use of digital media in education. The framework presented in this article is an essential new step toward a convergence of the research in this field. Only when researchers are aware of the complexity of the construct of teachers' attitudes toward science, when explicit and substantiated decisions have been made regarding which components and objects should be measured, and when methodologically sound instruments and interventions are used, can scientific progress be achieved in research on teachers' attitudes. Future research is needed to investigate the various aspects of the proposed framework, including the relationships between the components and the weights of the various components and sub-attributes in predicting behavioural intention. The investigation of these aspects is a prerequisite for gaining further insight into the dynamics of primary teachers' attitudes toward science and for the development of interventions that are better suited to improve specific aspects of teachers' attitudes.

\section{Keypoints}

- Professional development of primary teachers in science education should pay explicit attention to attitude improvements.

- Attitude research should be based on a theoretical model, such as the framework of attitude towards science.

- Primary teachers feel more in control over science teaching when they have gone through the inquiry process themselves.

- Primary teachers' attitudes towards teaching science can be improved by stimulating their own curiosity, scientific attitudes and thinking skills.

- Sound theoretical and methodological attitude research should be on the frontline of research in science learning.

\section{Acknowledgements}

Contract grant sponsor: Platform Beta Technology in The Netherlands.

\section{References}

Ajzen, I., \& Fishbein, M. (1980). Understanding attitudes and predicting social behavior. Englewood-Cliffs, NJ: Prentice-Hall. 
Asma, L.J.F., Walma van der Molen, J.H., \& van Aalderen-Smeets, S.I. (2011). Primary teachers' attitudes towards science: Results of a focus group study. In M.J. de Vries, H. van Keulen, S. Peters, \& J.H. Walma van der Molen (Eds.). Professional development for primary teachers in science. The Dutch VTB-Pro project in an international perspective (pp. 89-105). Rotterdam: Sense.

Barmby, P., Kind, P.M., \& Jones, K. (2008). Examining changing attitudes in secondary school science. International Journal of Science Education, 30, 1075-1093. doi: 10.1080/09500690701344966.

Bennett, J., Rollnick, M., Green, G., \& White, M. (2001). The development and use of an instrument to assess students' attitude to the study of chemistry. International Journal of Science Education, 23, 833-845. doi: 10.1080/09500690010006554.

Coulson, R. (1992). Development of an instrument for measuring attitudes of early childhood educators towards science. Research in Science Education, 22, 101-105. doi: 10.1007/BF02356884.

Eagly, A., \& Chaiken, S. (1993). The psychology of attitudes. Belmont, CA:Wadsworth group/Thomson Learning.

Gardner, P.L. (1995). Measuring attitudes to science: Unidimensionality and internal consistency revisited. Research in Science Education, 25, 283-289. doi: 10.1007/BF02357402.

Haney, J.J., Czerniak, C.M., \& Lumpe, A.T. (1996). Teacher beliefs and intentions regarding the implementation of science education reform strands. Journal of Research in Science Teaching, 33, 971-993. doi: 10.1002/(SICI)1098-2736(199611)33:9,971::AID-TEA2.3.0.CO;2-S.

Harlen, W., \& Holroyd, C. (1997). Primary teachers' understanding of concepts of science: Impact on confidence and teaching. International Journal of Science Education, 19, 93-105. doi: 10.1080/0950069970190107.

Jarvis, T., \& Pell, A. (2004). Primary teachers' changing attitudes and cognition during a two-year science inservice program and their effect on pupils. International Journal of Science Education,26, 17871811. doi: $10.1080 / 0950069042000243763$.

Osborne, J., Simon, S., \& Collins, S. (2003). Attitudes towards science: A review of the literature and its implications. International Journal of Science Education, 25, 1049-1079. doi: 10.1080/0950069032000032199.

Osborne, J., \& Dillon, J. (2008). Science education in Europe: Critical reflections (a report to the Nuffield Foundation). London: the Nuffield Foundation. Retrieved from http://www.pollen-europa.net/pollen dev/Images Editor/Nuffield report.pdf.

Pajares, M.F. (1992). Teachers' beliefs and educational research: Cleaning up a messy construct. Review of Educational Research, 62, 307-332. doi: 10.3102/00346543062003307.

Reid, N. (2006). Thoughts on attitude measurement. Research in Science \& Technological Education, 24, 327. doi: 10.1080/02635140500485332.

Tai, R. H, Liu, C. Q, Maltese, A. V, \& Fan, X. (2006). Planning early for careers in science. Science, 312, 1143-1145. doi: 10.1126/science.1128690.

Turner, S., \& Ireson, G. (2010). Fifteen pupils' positive approach to primary school science: When does it decline? Educational Studies, 36, 119-141. doi: 10.1080/03055690903148662.

Tosun, T. (2000). The beliefs of preservice elementary teachers towards science and science teaching. School Science and Mathematics, 100, 374-379. doi: 10.1111/j.1949-8594.2000.tb18179.x.

van Aalderen-Smeets, S.I., Walma van der Molen, J.H., \& Asma, L.J.F. (2012). Primary teachers' attitude toward science: A new theoretical framework. Science Education, 96, 158-182. doi: $10.1002 /$ sce. 20467.

van Aalderen-Smeets, S. I. \& Walma van der Molen, J. H. (2013a). Measuring primary teachers' attitudes toward teaching science: development of the Dimensions of Attitude towards Science (DAS) instrument. International Journal of Science Education, 35, 4, 577-600. doi:10.1080/09500693.2012.755576.

van Aalderen-Smeets, S. I. \& Walma van der Molen, J. H. (2013b). Improving primary teachers' attitudes toward science by attitude focussed professional development. (submitted). 
Walma van der Molen, J.H., Aalderen-Smeets, van, S.I., \& Groot Koerkamp, E. (2011). Cursusboek talentontwikkeling, wetenschap en techniek: Professionalisering voor basisschoolleerkrachten [Coursebook talent development, science, and technology: Professional development for primary teachers]. Knowledge Center for Science and Technology (KWTO).

Yates, S., \& Goodrum, D. (1990). How confident are primary school teachers in teaching science? Research in Science Education, 20, 300-305. doi: 10.1007/BF02620506.

\section{Appendix}

Schematic overview of the Science education-training course for primary teachers (Walma van der Molen, van Aalderen-Smeets \& Groot Koerkamp, 2011).

\begin{tabular}{|c|c|c|c|c|c|}
\hline & \multicolumn{3}{|c|}{ Content elements } & \multicolumn{2}{|c|}{ Take-home assignments } \\
\hline & $\begin{array}{c}\text { Attitude towards } \\
\text { (teaching) } \\
\text { science }\end{array}$ & $\begin{array}{l}\text { Scientific } \\
\text { attitudes }\end{array}$ & Scientific skills & $\begin{array}{c}\text { Personal } \\
\text { development }\end{array}$ & In Class \\
\hline 1 & $\begin{array}{l}\text { Creating } \\
\text { awareness about } \\
\text { view of science } \\
\text { Introduction on } \\
\text { Attitude toward } \\
\text { science }\end{array}$ & $\begin{array}{l}\text { Stimulating } \\
\text { teachers' } \\
\text { curiosity and } \\
\text { amazement about } \\
\text { everyday items }\end{array}$ & & $\begin{array}{l}\text { Keeping a Diary } \\
\text { of Amazement }\end{array}$ & $\begin{array}{l}\text { Identifying and } \\
\text { challenging } \\
\text { pupils views } \\
\text { about and } \\
\text { perceptions of } \\
\text { science }\end{array}$ \\
\hline \multicolumn{6}{|c|}{ Linking meeting 1 to 2: from amazement and curiosity to formulating research questions } \\
\hline 2 & $\begin{array}{l}\text { Challenging } \\
\text { cognitive beliefs } \\
\text { about the } \\
\text { relevance of } \\
\text { science and } \\
\text { stereotypical } \\
\text { gender beliefs } \\
\text { regarding science }\end{array}$ & $\begin{array}{l}\text { Stimulating } \\
\text { curiosity, } \\
\text { inquisitiveness } \\
\text { and question } \\
\text { asking, dealing } \\
\text { with scientific } \\
\text { uncertainty and } \\
\text { ambiguity }\end{array}$ & $\begin{array}{l}\text { Formulating } \\
\text { research } \\
\text { questions and } \\
\text { hypotheses }\end{array}$ & $\begin{array}{l}\text { Evaluating a } \\
\text { science education } \\
\text { method or related } \\
\text { medium } \\
\text { (website, TV) } \\
\text { with attitudinal } \\
\text { criteria }\end{array}$ & $\begin{array}{l}\text { How many } \\
\text { Difficult } \\
\text { questions can you } \\
\text { think of? }\end{array}$ \\
\hline \multicolumn{6}{|c|}{ Linking meeting 2 to 3: from research questions to research design and enjoying science } \\
\hline 3 & $\begin{array}{l}\text { Challenging the } \\
\text { affective } \\
\text { component of } \\
\text { attitude, i.e. } \\
\text { enjoyment and } \\
\text { anxiety }\end{array}$ & $\begin{array}{l}\text { Stimulating a } \\
\text { critical attitude }\end{array}$ & $\begin{array}{l}\text { Choosing } \\
\text { research method } \\
\text { and design, and } \\
\text { conducting } \\
\text { research in the } \\
\text { classroom }\end{array}$ & $\begin{array}{l}\text { Self-observation: } \\
\text { Searching for } \\
\text { opportunities to } \\
\text { integrate science } \\
\text { in your existing } \\
\text { lessons }\end{array}$ & $\begin{array}{l}\text { Conducting } \\
\text { research in the } \\
\text { classroom; from } \\
\text { research question } \\
\text { to experiment }\end{array}$ \\
\hline \multicolumn{6}{|c|}{ Linking meeting 3 to 4: not only hands-on but minds-on; stimulating academic thinking skills } \\
\hline 4 & & $\begin{array}{l}\text { Being persistent, } \\
\text { creative and } \\
\text { original }\end{array}$ & $\begin{array}{l}\text { Creative and } \\
\text { higher order } \\
\text { thinking skills; } \\
\text { developing a } \\
\text { Thinking lesson }\end{array}$ & $\begin{array}{l}\text { Improving an } \\
\text { existing science } \\
\text { method }\end{array}$ & $\begin{array}{l}\text { Stimulating } \\
\text { creative thinking } \\
\text { in children }\end{array}$ \\
\hline
\end{tabular}


Linking meeting 4 to 5: independence of context factors and being in control of science teaching

5 Stimulating self- Using different Stimulating

efficacy and perspectives to reflective and Developing and teaching a science

perceived control solve problems metacognitive lesson

thinking skills

Linking meeting 5 to 6: from feeling in control to actually teaching science

6 Summary of training course

Participant's presentations of visual reports on science lessons

Note that this figure provides a schematic overview. Several additional attitudinal elements are interwoven in the course. Also spontaneous questions and comments from the participants that came up during the course were explained in terms of attitude or related to attitude toward science and scientific attitude. The first four columns are aimed at the personal development of the teacher. The In Class, Take home assignments are explicitly aimed at the interaction with pupils. 